\title{
OVERVIEW OF BRAZILIAN RESEARCH ON STATISTICS EDUCATION INVOLVING TEACHERS: METHODOLOGICAL PATHS AND TRAINING CONTEXTS
}

\author{
DOUGLAS DA SILVA TINTI \\ Federal University of Ouro Preto \\ tinti@ufop.edu.br \\ CELI ESPASANDIN LOPES \\ Cruzeiro do Sul University \\ celi.espasandin.lopes@gmail.com
}

\begin{abstract}
This article aims to analyze Brazilian research on statistics education involving teachers to highlight methodological trends and training contexts mobilized by such research. To this end, a survey was carried out in the Dissertation and Thesis Bank of CAPES, considering the descriptor "Statistical Education" and the 2013-2018 timeframe. A total of ninety-nine studies were found, twenty of which met the proposed objective. This is a documentary and bibliographic study, in which an interpretative approach was adopted using the technique of content analysis. The data analysis verified that nine of those studies did not lead to training processes with teachers. In addition, the analysis of the other eleven studies, which led to training, revealed an intrinsic relationship between the methodological path and the training contexts reported. This demonstrated the expressiveness of training contexts based on epistemology of collaboration, that is, those contexts that both give voice and listen to teachers and recognize them as producers of knowledge. Conversely, we identified two research studies that shaped the training considering the paradigm of technical rationality, and designed training courses to address certain content/concepts that teachers supposedly do not master. It was evidenced that the conception of teacher training has a direct and explicit relationship with the organization of the training spaces outlined. Finally, we identified one research study based on epistemology of practice, which focuses on the understanding of knowledge mobilized in teaching practice.
\end{abstract}

Keywords: Statistical education research; Teacher training; Professional development

\section{INTRODUCTION}

The daily life of contemporary society is centered on the use of digital technologies, which promote a rapid and constant production of information on significant range of themes. This movement of life requires people to perform brief analyses to guide them to make the right decision. Thus, statistical and probabilistic knowledge is essential to the education of each and every person.

Considering this reality, the mathematics curriculum in most countries includes studies of probability and statistics from primary education. In Brazil, the Common National Curricular Base ([BNCC ] Brazil, 2017) is being implemented. In that document, the area of Mathematics presents a thematic unit on probability and statistics to be studied from the early years of primary education (children aged between 6-14 years). The objects of knowledge and skills to be developed are described, and the importance of collecting, organizing, representing, interpreting and analyzing data in a variety of contexts is emphasized. These skills are needed to make informed judgments and make appropriate decisions in different circumstances. It is also noteworthy that it is necessary to expand reasoning and the use of concepts, representations and statistical indexes to describe, explain and predict phenomena.

This increases the attention of teachers and researchers to reflect and find out what, why, and how to teach content related to statistics, probability and combinatorics. It is necessary to break free from the deterministic aspect of mathematics classes, which stresses the value of formulas, calculations and 
procedures. The research in statistics education expands and propagates within the scope of Brazilian education. Cazorla et al. (2010) consider that:

Statistics education is a research area that aims to study and understand how people teach and learn statistics, which involves cognitive and affective aspects of teaching-learning, besides the epistemology of statistical concepts and the development of teaching methods and materials etc., aiming at the development of statistical literacy. (pp. 22-23)

Campos et al. (2011, p. 12) complement this perspective. They consider that the teaching of statistical concepts occurs through the development of skills such as literacy, reasoning and statistical thinking in order to value "an investigative, reflective and critical posture of the student," considering the globalization of society, which focuses on the accumulation of information and the need to make decisions in situations of uncertainty. These authors point out that statistical literacy refers to the ability for statistical communication, statistical reasoning involves connection or combination of ideas and statistical concepts, and statistical thinking refers to the ability to relate quantitative data to concrete situations, considering the presence of variability and uncertainty and selecting the appropriate statistical tools for the analysis process.

Statistical education, as an area of educational research in Brazil, is organized by research groups certified by teaching and research institutions registered with the National Research Council (CNPQ). In general, the dialogue among these groups has taken place through the Working Group on Statistics education-GT12 of the Brazilian Society for Mathematical Education (SBEM). Within this context, we aim to present an overview of the research that involved teachers and was developed and published in the 2013-2018 period. Lopes (2013) submitted a discussion on Brazilian research focused on continuing teacher training and stressed that collaborative and cooperative work was considered of critical importance for the learning processes of teachers. Since then, many study and research groups have been created based on partnerships between universities and schools aimed at collaborative work among professors and researchers. The present study provides a view of the academic production built on the relationship between teacher education and statistical education. The analysis is a part of the post-doctoral research of the first author, under the supervision of the second author.

\section{METHODOLOGICAL PATH}

This article aims to analyze Brazilian research about statistics education involving teachers in order to highlight methodological trends and training contexts mobilized by such research studies. To this end, a survey was carried out at the Dissertation and Thesis Bank of the Coordination for the Improvement of Higher Education Personnel (CAPES; retrieved from: June 1, 2019, http://catalogodeteses.capes.gov.br/catalogo-teses/), considering the descriptor "Statistical Education" and the period between 2013 and 2018, as well as the survey perspective defined by Fiorentini et al. (2016, p. 18), that is:

[...] a systematic process of survey and description of information about the research produced on a specific field of study, covering a certain location (place) and length of time. This information relates to the physical aspects of this production (describing where, when and how many studies were produced over the period, and who the authors and participants of this production were), as well as their theoretical-methodological and thematic aspects.

Considering the criteria described, a total of ninety-nine studies were identified, as shown in Table 1.

Table 1. Categorization of research surveyed according to course modality

\begin{tabular}{lcc}
\hline Course & Total & $\%$ \\
\hline Academic Masters & 40 & 40.40 \\
Professional Masters & 32 & 32.33 \\
Doctorate & 27 & 27.27 \\
\hline Total & 99 & 100 \\
\hline
\end{tabular}


From this database, we started reading the abstracts and tabulating the data. From this tabulation it was possible to sort the ninety-nine research studies according to the target audience involved in the investigation, as shown in Table 2. The data in the table show that twenty of the studies surveyed are in dialogue with the proposed objective, that is, they were developed with mathematics teachers. Taking this into account, the public involved in the research was adopted as the first exclusion criterion for the research to be analyzed in greater depth. However, the fact of these involved teachers did not necessarily mean that training processes took place with the teachers. Thus, we conducted a full reading of the 20 research papers in an attempt to identify which of them developed teacher training processes aimed at producing data from their research. According to this parameter (second exclusion criterion), we identified that eleven studies fitted into this scenario, which is the focus of the analysis of this article.

Table 2. Categorization of research analyzed according to the pubic involved

\begin{tabular}{lcc}
\hline Public involved in the research & Total & $\%$ \\
\hline Early Childhood Education Students & 1 & 1.01 \\
Students in the first years of Elementary School & 7 & 7.07 \\
Students in the last years of Elementary School & 7 & 7.07 \\
Students in the first and last years of Elementary School & 2 & 2.02 \\
Secondary students & 14 & 14.14 \\
Students in Youth and Adult Education & 3 & 3.03 \\
High School graduates & 1 & 1.01 \\
Vocational High School Students & 1 & 1.01 \\
Students pursuing Associate Technological Degrees & 1 & 1.01 \\
College Students & 11 & 11.11 \\
Pre-service Training & 10 & 10.10 \\
In-Service Training & 20 & 20.20 \\
Research of a bibliographic or documental nature & 9 & 9.09 \\
Not explained in the abstract & 12 & 12.12 \\
\hline Total & 99 & 100 \\
\hline
\end{tabular}

From this corpus, for the categorization process, we considered the research of Nacarato (2011), which noted three major concepts or paradigms of teacher training. we conducted a new reading in full of the eleven studies, seeking to detect characteristics that point to the presence of one of these training concepts or paradigms. In this direction, the analysis of the research that triggered training processes revealed an intrinsic relationship between the methodological path and the training contexts reported. A significant number of training contexts was observed, based on the epistemology of collaboration, that is, those that gave voice and listen to teachers, who recognized them as producers of knowledge. We also found two research projects that structured the training considering the paradigm of technical rationality, that is, two works designed training courses to address certain contents/concepts that teachers supposedly do not master. Finally, we identified a research project based on the epistemology of practice, that is, the research focused on the understanding of knowledge mobilized in teaching. It must be noted that these elements will be detailed in the analysis presented in this article.

As shown in Table 3, this movement of data analysis and categorization enabled us to identify that nine of these studies did not trigger training processes with teachers. These are studies that investigated, for example, conceptions, perceptions of teachers by means of questionnaires and semi-structured interviews. Considering the objective of this article, such research will not be inserted in the corpus of analysis. 
Table 3. Conception or paradigm of teacher training included in the research studies

\begin{tabular}{lcl}
\hline Training conception or paradigm & Total & \multicolumn{1}{c}{ Research studies } \\
\hline $\begin{array}{l}\text { Did not develop teacher training } \\
\text { processes }\end{array}$ & 9 & $\begin{array}{l}\text { Bianchini (2013), Oliveira (2014), Teixeira (2015), E. Araújo } \\
\text { (2017), Teixeira (2017), Cardoso (2018), Gonçalves (2018), } \\
\text { Rodrigues (2018), Votto (2018) }\end{array}$ \\
Paradigm of technical rationality & 2 & $\begin{array}{l}\text { Bifi (2014), Martins (2014) } \\
\text { Epistemology of practice }\end{array}$ \\
$\begin{array}{l}\text { Epistemology of collaboration } \\
\text { M. Araújo (2017) }\end{array}$ \\
\end{tabular}

It should be noted that the present article is a documentary and bibliographic study in which an interpretative approach was adopted using the analysis of content technique (Flick, 2009). In the next section, we present the characteristics that were used to sort the research.

\section{ANALYSIS}

To achieve the proposed objective, we needed to seek support in the concepts of teacher training that guide the constitution/proposition of training spaces and, at the level of academic research, the methodological tools used to collect data. In this sense, we resorted to the study of Nacarato (2011), which indicates the existence of three conceptions or paradigms of teacher training: technical rationality; epistemology of practice and epistemology of collaboration.

In the understanding of Nunes (2001):

In the Brazilian reality, educational research on school practice seem to prioritize two types of interest that constitute knowledge, according to Haberman (in Fiorentini, 1998): the instrumental technical interest, in which objective scientific explanations are used, based on the model of technical rationality; and the practical interest, which effectively interprets the meanings produced by practitioners of the world-life as a subsidy for the issuance of a practical judgment. There would also be a third interest that would be the emancipatory interest, one that "requires any narrow and uncritical interpretations of subjective meanings to be overcome in order to achieve an emancipatory knowledge that allows evaluation of the social, cultural and political conditions/determinations in which communication and social action are produced." (p. 315)

However, when we look at the data in Table 3, it is evident that, in the field of Brazilian research in statistical education, training practices based on collaboration seem to have prevailed. We agree with the view of Nóvoa (1995) who states that:

Training is not built via accumulation (of courses, knowledge or techniques), but rather through critical reflective work on practices and the permanent (re)construction of a personal identity. That is why it is so important to engage the person and provide a status to the knowledge of experience. (p. 25)

Next, we will make some considerations about each teacher training conception or paradigm and we will analyze the research that fit each categorization.

\subsection{TEACHER TRAINING IN STATISTICS EDUCATION FROM THE PERSPECTIVE OF TECHNICAL RATIONALITY}

Nacarato (2011) indicated that the perspective of technical rationality, in which the teacher is seen as a technician (or user) and not as a producer of knowledge, was present in the training spaces up to the 90s. However, even today it can be present in the conception and structuring of training spaces that aim to apply knowledge produced by agents external to the school, the experts; therefore, not recognizing teachers as producers of knowledge.

The research developed by Bifi (2014) sought to answer the following research interrogation: What statistical-didactic and specific knowledge is mobilized in situations of design and management of 
classes by a group of teachers in their teaching practices? This was a case study involving nine teachers from the final years of elementary school in which the training context consisted of meetings with teachers in the Collective Pedagogical Work Hours (HTPC) from 2010 to 2013.

The research was organized in three phases: group observation and practical observation in the classroom, which allowed the development of activities relating to the "Treatment of Information" knowledge strand; presentation of this strand to the research group; and, finally, an interview. (Bifi, 2014, p. 22)

Although it is recognized that the HTPC can be configured as a space for study and for sharing of knowledge and teaching practices, Bifi (2014) suggested that there was an effort to observe and identify the knowledge that the teachers had, or lack thereof, so that the researcher (expert) may then propose activities that could potentially remedy such gaps. In addition to the researcher, the presence of two other specialists in the HTPC space was evidenced in the research: the pedagogical coordinator and a teacher, who held a MSc in mathematics teaching. In the report Bifi stated:

The questions made to the research subjects ranged from objective questions, of immediate response, to analysis of activities involving important notions of statistics [...]. In this phase, we were concerned with seeking evidence on the didactic knowledge of content that teachers mobilize when addressing the topics of Information Treatment [...]. (p. 23)

Besides the presence of experts, it was evident in Bifi's research (2014) that there was an absence of recognition of the teacher as a producer of knowledge. Just like Martins (2014), Bifi was concerned with highlighting what teachers know and what they do not know. However, the research of Martins (2014) focused on a more technical interrogation, beyond content, which was the use of software programs in educational contexts.

The training context presented in Martins' research (2014) indicated that meetings were held with four teachers, who teach children aged 6-10 years, with the following guiding question: "What are the conceptions of teachers of early childhood education about sampling through the use of the TinkerPlots software?" The meetings with the teachers, had the purpose of familiarizing the teachers with the TinkerPlots software. The purpose of the activities that were proposed to the teachers was to check their understanding of the processes of construction, organization and data analysis. According to Martins,

Based on these steps, we can conclude that the teachers participating in this study were able to handle the tools of the TinkerPlots software, with the help of the researcher, and learned its purpose for working with sampling. The teachers interacted with the main tools of the Plot menu, as well as the key components of the Sampler tool. (p. 75)

To supplement these considerations, Martins (2014) highlighted the presence of the perspective of technical rationality as described by Nacarato (2011). We observed the concern regarding the training of teachers for the specific use of a given software program and the work with a distinct methodological perspective in the classroom.

The indications found in the research suggest that the teachers were able to initially understand representativeness and its relationship with the sample size. The notion of representativeness was always present as a concern of the teachers. This demonstrated their understanding of the context of use of sample searches. (Martins, 2014, p. 147)

In methodological terms, the collection of data from the two studies under analysis was based on questionnaires, interviews, and fieldwork logs. It became evident that the analysis of the data that emerged from the research based on a perspective of technical rationality was limited to describing difficulties and the knowledge that the teachers had or not. Such context does not hold a dialogue with more encompassing knowledge of teaching practice. Moreover, it does not favor mobilization of reflective processes that corroborate a process of autonomy and self-training of teachers.

\subsection{TEACHER TRAINING ON STATISTICS EDUCATION FROM THE PERSPECTIVE OF THE EPISTEMOLOGY OF PRACTICE}

The perspective of epistemology of practice described by Nacarato (2011) indicated that professional practice shapes teachers, and the knowledge derived from experience validated and configured other types of knowledge that make up the repertoire of professional knowledge (specific 
knowledge of content, pedagogical knowledge of content, curriculum knowledge, knowledge of educational sciences, among other types of knowledge). In this sense, training contexts based on this perspective provided different reflections on teaching practice.

M. Araújo (2017) investigated the teaching related to the treatment of information knowledge strand within the context of continuing education of teachers of the early years of elementary education using WebQuest in order to enable reflections, understandings and learning about life experiences, production of knowledge and teaching attitudes. The title of Araújo's research may suggest that, because it makes use of a technical resource (WEBQUEST software), it might be guided by the perspective of epistemology of technical rationality. However, it is important to observe the presence of reflection on the practice in alignment with the research objective. Consider what stands out in two of its specific objectives:

b) Provide working teachers with training moments that favor reflections about teaching practices in the treatment of information using digital technologies;

c) Contribute to the production of new knowledge and teaching practices that favor more socially relevant teaching on treatment of information. (p. 39)

M. Araújo (2017) indicated that the training context derived from the research consisted of meetings with about fifteen teachers from the first years of elementary school, totaling 60 hours of work. In the author's description of the meetings, it was possible to identify opportunities to read and debate academic texts, joint development of school activities, writing of narratives, development activities in the schools, and socialization of experiences.

This way, they demonstrate the meanings attributed to this investigative experience as a fertile ground for the socialization of teaching practices, approximation of discussions about teaching and recognition/evaluation of their voices and knowledge in the educational context, which provides greater assurance in the dichotomic relationship between theory and practice of this curricular component, thus providing a fruitful scenario for curiosity, questioning, uncertainty, interactions, and re-articulations, in addition to enabling (re)significations. At this moment, they also develop reflection regarding the experience lived, mobilizing knowledge and experiences in order to clarify the problem under inquiry. (p. 69)

As we can see, technical rationality is opposed to practical rationality, which values knowledge from experience and reflection on one's own practice. Therefore, in methodological terms, the construction of data considers not only the questionnaires, interviews and fieldwork logs, but also narratives and intervention projects of the teachers involved.

\subsection{TEACHER TRAINING ON STATISTICS EDUCATION FROM THE PERSPECTIVE OF EPISTEMOLOGY OF COLLABORATION}

Nacarato (2011) indicated that, since the end of the 1990s, an articulation has been sought between practical and reflective training with theoretical reflection; this concept was named training of collaboration epistemology. The author also emphasized in this concept that "teachers are seen as professionals who need collaboration and partnerships for their professional development" (p. 32).

According to Tinti (2017):

This conception is in line with what current trends in research in the field of mathematical education have pointed out, i.e., the need to listen to teachers who work in public schools and who face the daily challenges and complexity of their teaching profession. They can contribute with their experience and their knowledge to the development of studies about teaching practice. (p. 36)

Moreover, Costa and Oliveira (2019) stressed the need to understand collaborative work "as a practice that is not imposed, but rather built by the participating members of groups; it involves trust, sharing of ideas and mutual help to achieve common goals" (p. 106). In this sense, an analysis of the objectives and/or guiding interrogations of the research that fall into this category demonstrate the presence of the following expressions: training project, teacher groups, communities of practice, training processes, training spaces, collaborative group, among others, which are based on the 
perspective of the epistemology of collaboration. Such expressions enabled us to group the studies according to the training contexts in which they were developed, as shown in Table 4.

Table 4. Training contexts present in the research based on epistemology of collaboration

\begin{tabular}{ll}
\hline Training context & Research \\
\hline Collaborative groups & $\begin{array}{l}\text { C. Souza (2013), Mendonça (2015), } \\
\text { Oliveira (2016) }\end{array}$ \\
Proposals for training groups & $\begin{array}{l}\text { L. O. Souza, (2013), Junqueira (2014), } \\
\text { Macedo (2016), Serra (2016) }\end{array}$ \\
Communities of practice & Estevam (2015) \\
\hline
\end{tabular}

Training contexts involving collaborative groups and teacher training on statistics education. A. C. Souza (2013) sought to answer the following question: "What contributions can the learning process of teachers, focused on reflection on practice make to the inclusion of statistics education in childhood schooling?" The research was carried out with the participation of a group of six teachers who teach in early childhood education and the first year of elementary school. The author explained that the meetings of the group included readings and discussions, problem solving, experiments and simulations on probability, combinability and statistics. These were based on the following premise: create opportunities for teachers to have a voice to share doubts, fears, joys and successes; and to have a space for creation.

To build data, A. C. Souza (2013) used interviews, audio and video recordings, photos and written texts (field logs and activities developed by the teachers). The author also pointed out that the activities conducted pointed to an important learning enhancing practice. We observed that, in order to organize the data, A. C. Souza (2013) used a data categorization strategy; whose categories emerged throughout the research. The author concluded that, throughout the study, it was found that the participation in the group contributed to the expansion of the teachers' professional knowledge and led to an approximation with statistical education, once the teachers were able to share their experiences; their work was valued and they valued the work of their peers; they revealed their thoughts and emotions about what they did not yet know and/or felt unable to do; and they reflected on their practice, which led to transformations.

The meetings of a collaborative group of mathematics teachers were the object of investigation by Mendonça (2015). The group was referred to as the Group for Research and Training in Statistical Education (GIFEM). At the time the research was carried out, GIFEM was comprised of five elementary education teachers and two university professors. The working agenda of the group was negotiated every semester and included the topic to be studied by the members. In 2013, GIFEM started studies on mathematical modeling and this topic was explored by the author. In this context, the research objective defined by Mendonça was to expand understanding about actions that enable some teachers to understand the process of doing mathematical modeling in the classroom, as an approach to statistical education. To this end, the following data construction tools were used: fieldwork log, audio and video recordings of meetings, and classroom activities.

The data analysis proposed by Mendonça (2015) was based on the categorization of the data, which emerged from the projects developed by the teachers. Regarding the results, the author pointed out that it was considered that the experience of some theoretical actions (reflection on teaching cases, analysis of ready-made mathematical models) and practical actions (development of modeling activity as a student, and development and implementation of modeling activities), with the support of peers, in the space for discussion in the group, could facilitate processes of reflection and action on modeling in elementary education.

Oliveira's research (2016) aimed to: identify whether and how statistical content is handled by teachers of the early years of elementary schools of the Xukuru do Ororubá people and analyze the planning and implementation of classroom activities involving steps of the statistical investigative cycle, developed within a collaborative group. This study involving continuing, voluntary and collaborative training of indigenous teachers was carried out in the spaces (in loco) of the Xukuru of Ororubá people in the state of Pernambuco (PE). The author pointed out that the movement to approach this group of teachers was due to respect and appreciation for the culture and knowledge of this people. 
She also pointed out that four face-to-face meetings were held with the collaborative group comprised of eleven teachers. In these meetings, there were conceptual discussions, elaboration and individual socialization of a lesson plan aimed at working with statistics content.

In order to build data, Oliveira (2016) considered the following instruments: observation, interviews, and class logs of the participating teachers. In this sense, the data analysis was structured by means of categories that emerged from the data construction instruments proposed in the research. Regarding the findings, Oliveira (2016) stated that the proposal for creating the collaborative group contributed to boost the development of statistics education in Xukuru do Ororubá indigenous schools, thus enabling the protagonism of teachers and their active participation in learning processes within the indigenous community.

Training contexts involving proposals for courses and teacher training in statistical education. $\mathrm{L}$. O. Souza (2013) sought to answer the following research interrogation: "What actions in a continuing education project contribute for teachers to develop and mobilize knowledge in the process of teaching and learning statistics?" To carry out the research, L. O. Souza proposed a project based on the perspective of collaborative action research. This project was called Cyclical and Continuing Professional Training of Statistics Teachers (FPCCPE), which involved 16 mathematics teachers working in the final years of elementary school. The FPCCPE was developed through eleven meetings with the teachers. As data construction instruments, L. O. Souza (2013) considered six questionnaires and video recordings of the meetings with the group. Data analysis was based on the categories that arose from the activities developed by the group.

Regarding the findings of the research, L. O. Souza indicated that the results showed that teachers who work collaboratively seem to begin to overcome their insecurities about teaching statistics. In this sense, teachers start to use an investigative and exploratory approach and improve their conceptual and content knowledge. The author highlighted that, among those teachers who participated in the project, nine were effectively able to develop new activities and approaches to introduce statistics in their classes, thus improving the students' learning. However, L. O. Souza (2013) stated that the development of FPCCPE indicated that training actions provide subsidies for teachers to expand their knowledge in a multidimensional development, thus generating significant understanding on the part of teachers about methods for teaching and learning statistics in elementary school mathematics classes.

Before proceeding, it is important to highlight that the research of Junqueira (2014), Macedo (2016) and Serra (2016) were developed under the Education Observatory Program (OBEDUC) of CAPES (retrieved from https://www.capes.gov.br/educacao-basica/observatorio-da-educacao).

The objective of the research of Junqueira (2014) was to understand teachers' conceptions about the basic concepts of probability, through a training process based on a design experiment methodology. Therefore, the research context was a training process developed with twenty-three teachers from junior high school and high school, in the public-school system, in the State of São Paulo, which were members of OBEDUC. This training process was structured via nine face-to-face meetings and ten remote meetings, with Virtual Learning Environment (VLE) as support. In this context, the instruments used for data construction were film and audio recordings of face-to-face interactions, records of the VLE (forums, portfolios), and logbooks.

Regarding the procedure of data analysis, Junqueira (2014) used categorization, which emerged from the analysis of the training meetings. The author indicated that the analysis showed that many of the interrogations, misunderstandings and misconceptions, present in most of the works consulted, were also found, particularly about conditional probability, independent and mutually exclusive events, and some fallacies, such as that of representativeness and that of the player. According to Junqueira (2014), with regard to training, the research also detected some conceptions related to the teachers' practice in the classroom, among them, some fragility in planning and reflecting on their teaching action, and little practice and some resistance regarding the use of technology in the educational process. However, they felt motivated with resources which were familiar to their teaching repertoires.

The training context investigated by Macedo (2016) was a face-to-face course held in six four-hour meetings, totaling twenty-four hours. In such meetings, participants developed and reflected on activities proposed by Macedo (2016) involving statistical literacy, particularly the interpretation of the normal curve. In this context, the author outlined the following objective for the research: to investigate the expansion of the knowledge base of a group of teachers of mathematics, in order to teach high 
school students the notions involved in reading the normal curve, through continuing education, whose assumptions were shared reflections and experiences on innovations presented in the most recent curricula on statistics and probability. For the construction of data, Macedo (2016) used audio and video recordings of meetings and reports developed by participants. Data analysis was organized into categories, which emerged from the analysis of the activities proposed.

With regard to the results, Macedo (2016) concluded that the reflections made during the training process broadened the teachers' knowledge base to teach statistics and probability. Moreover, the author pointed out that the results of this study also indicated the need for these training processes to have an articulation between different approaches, strategies, contexts and materials for the processes of teaching and learning notions related to the theme under study.

Serra's research (2016) aimed to investigate the expansion of the knowledge base of a group of mathematics teachers of elementary education to teach students in the final years of primary and secondary education how to read and build statistical graphs. This was done through continuing education, whose assumptions were shared reflections on statistical literacy and difficulties to teach notions related to the topic. Serra $(16$, p. 106) indicated that the course was broken down into eight 4hour weekly meetings, four of which were dedicated to the study of graphics, the object of the research. The author also pointed out that the activities proposed by the trainer were discussed in groups, but each participant wrote their own report. Fifteen mathematics teachers attended the proposed training. For the construction of data, the author used questionnaires and reports prepared by the participants after performing the activities proposed. The data analysis was structured into categories, which arose from the analysis of the activities developed.

Regarding the results, Serra (2016) stated that the discussions and reflections held during the training process broadened the knowledge base of teachers for teaching the topic. Similar to Macedo (2016), Serra also highlighted that the results of this study also point to the need for including in training processes an articulation among different approaches, strategies and materials for the processes of teaching and learning notions relating to statistics.

Training contexts involving communities of practice and teacher training on statistical education. The setup and the meetings of the Community of Practice - Reflecting, Discussing and Acting on Mathematics (CoP-ReDAMat) were the context investigated in the research of Estevam (2015), which was structured in a multipaper format. Initially, the CoP-ReDAMat included five mathematics teachers, two mathematics graduates and the researcher. Throughout the research, Estevam listed who the members of $\mathrm{CoP}$ were, given that the members entered and exited the $\mathrm{CoP}$ at different times. The author sought to answer the following research interrogation: "How do the undertakings of a group of mathematics teachers, recognized as a Community of Practice, provide opportunities for professional development in statistical education?"

For the construction of data, Estevam (2015) used transcriptions of audio recordings of the meetings held by CoP-ReDAMat. The analysis of such transcriptions led to the development of units of analysis, which were considered by the author to present the results of the study. Estevam concluded that the chances of professional development provided in $\mathrm{CoP}$ contexts were not anchored in the undertaking itself. Rather, they emerged from the articulation between what was developed within the undertaking and the practices performed by teachers in their daily actions, which, based on the elements we identified, are a conditioning factor for the learning of teachers.

\section{SOME CONSIDERATIONS}

The analytical process explored Brazilian research studies on statistics education published in the database of theses and dissertations of CAPES, between 2013 and 2018. The research undertaken involved proposals for continuing training of mathematics teachers and was examined in order to highlight methodological trends and training contexts. The analysis revealed that the concept of teacher training has a direct and explicit relationship with the organization of training spaces. This consideration is based on the analysis carried out in this survey that enabled us to observe differences in the participation of teachers during the construction of data in training spaces. While L. O. Souza (2013) described a training action that enabled teachers to jointly build their training journey, in the research 
of Junqueira (2014), Macedo (2016) and Serra (2016) the training proposal was outlined in the format of a course in which teachers discussed activities, which were previously developed by the trainers.

In training activities based on technical rationality, that is, those that do not recognize the teacher as a producer of knowledge, the research data collection was limited to questionnaires, interviews and fieldwork logs. The results of the current analysis pointed out by these studies tend to blame teachers, drawing attention to what teachers know and what they do not. In comparison, when we analyzed research in which the training space was based on technical rationality, we observed a trend to expand the data constructed in questionnaires and interviews, which enabled research participants to develop projects and narratives of their practices. The results of these research studies foster a dialogue between theory and practice.

There are also teacher training contexts that are structured under a collaborative perspective. Among the research studies that are consonant with this scenario, we observed the presence of three possible training contexts: those mobilized in collaborative groups, those derived from a proposal of a training course, and those which adopted the perspective of a community of practice.

The use of data construction tools that value the trajectory of the group and the knowledge mobilized becomes evident in the analyses of research developed within the dynamics of collaborative groups and communities of practice. In this regard, the use of audio and video recordings of meetings, records of participants and the researcher themselves prevails. It has also been observed that data analysis is not defined a priori. Instead, it spawns from the investigative process. Thus, the analysis of the studies submitted by the researchers value the knowledge and practices of teachers, thus overcoming the perspective of technical rationality.

It should also be considered that, although some research studies indicated that they were conceived in a collaborative perspective, the description of the context in the research papers does not seem to contemplate such intention. This study revealed evidence that collaborative work in statistical education, within the scope of continuing teacher training, takes place in small groups, in different contexts and with isolated actions of teaching and research institutions. This shows the lack of public policies that consider this training perspective, which renders more effective results in changing the practices of teachers when teaching probability and statistics. Based on such evidence, we can consider that the present study was a contribution to the area of research in statistical education, by disclosing theoretical and methodological diversities, in a different context of a Latin American country with large territorial dimensions and cultural and social heterogeneity.

\section{REFERENCES}

Araújo, E. L. (2017). Concepções de Educação Estatística: narrativas de professores membros do GT12 da SBEM. [Conceptions of statistical education: Narratives of teachers participating in SBEM GT-12 ] [Masters thesis, Universidade Federal do Pará, Brasil].

Araújo, M. J. L. (2017). Práticas investigativas e Webquest: construindo interfaces para o ensino sobre tratamento da informação para além do paradigma do exercício. [Investigative practices and webquest: Building interfaces for teaching information treatment beyond the exercise paradigm] [Masters thesis, Universidade Federal do Pará, Brasil].

Bianchini, D. F. (2013). Práticas pedagógicas em Estatística dos anos iniciais: Realidades e possibilidades. [Pedagogical practices in statistics of the early childhood education: Realities and possibilities] [Masters thesis, Universidade Regional do Noroeste do Estado do Rio Grande do Sul, Brasil].

Bifi, C. R. (2014). Conhecimentos estatísticos no Ciclo I do Ensino Fundamental: Um estudo diagnóstico com professores em exercício. [Statistical knowledge in elementary school: A diagnostic study with in-service teachers] [Doctoral dissertation, Pontifícia Universidade Católica de São Paulo, Brasil].

Brasil. (2017). Ministério da Educação. Base Nacional Comum Curricular [Common Base National Curriculum]. Brasil: Ministry of Education and Culture.

Campos, C. R., Wodewotzki, M. L., \& Jacobini, O. R. (2011). Educação Estatística: Teoria e prática em ambientes de modelagem matemática. [Statistical education: Theory and practice in mathematical modeling environments] Autêntica. 
Cardoso, L. M. F. (2018). Um estudo da abordagem da Estatística nos anos finais do Ensino Fundamental e no Ensino Médio em escolas públicas estaduais do município de Barbacena-MG. [A study of the statistics approach in the junior high and high school in the public-school system of Barbacena-MG] [Masters thesis, Universidade Federal de São João del-Rei, Brasil].

Cazorla, I. M., Kataoka, V. Y., \& Silva, C. B. (2010). Trajetórias e perspectivas da Educação Estatística no Brasil: Um olhar a partir do GT 12. [Trajectories and perspectives of statistical education in Brasil: A look from GT 12]. In C. E. Lopes, C. Q. S. Coutinho, \& S. A. Almouloud (Eds.), Estudos e reflexões em Educação Estatística (pp. 19-44). Mercado de Letras.

Costa, W. O., Oliveira, A. M. P. (2019). A participação de professores na elaboração de tarefas matemáticas em um trabalho colaborativo. [The participation of teachers in the elaboration of mathematical tasks in a collaborative work] Revemop, 1(1), 105-125.

Estevam, E. J. G. (2015). Práticas de uma comunidade de professores que ensinam matemática e o desenvolvimento profissional em educação matemática. [Practices of a community of teachers who teach mathematics and professional development in mathematics education] [Doctoral dissertation, Universidade Estadual de Londrina, Brasil].

Fiorentini, D., Passos, C. L. B., Lima, R. C. R. (Eds.). (2016). Mapeamento da pesquisa acadêmica brasileira sobre o professor que ensina matemática: Período 2001-2012. [Mapping of Brazilian academic research on the teacher who teaches mathematics: Period 2001-2012]. FE/UNICAMP. https://www.fe.unicamp.br/pf-fe/pagina_basica/58/e-book-mapeamento-pesquisa-pem.pdf

Flick, U. (2009). Introdução à pesquisa qualitativa. [Introduction to qualitative research] Artmed.

Gonçalves, M. C. (2018). Reflexões sobre o ensino de Estatística na Educação Básica. [Reflections regarding the teaching of statistics in elementary education] [Masters thesis, Universidade Federal do Rio de Janeiro, Brasil].

Junqueira, A. L. N. (2014). Probabilidade na educação básica: Uma abordagem do design experiment na formação continuada de professores. [Probability in elementary education: A design experiment approach in continuous education of teachers] [Doctoral dissertation, Universidade Anhanguera de São Paulo, Brasil].

Lopes, C. E. (2013). O desenvolvimento profissional de professores em educação estatística nas pesquisas brasileiras. [The professional development of teachers in statistical education in Brazilian research] In A. Salcedo (Ed.), Educación Estadística en América Latina: Tendencias y perspectivas (pp. 229-255). PCI; UCV.

Macedo, R. C. (2016). Conhecimentos de professores de Matemática sobre o processo de ensino e de aprendizagem de noções estatísticas - curva normal. [Knowledge of mathematics teachers regarding teaching and learning fundaments of statistics] [Masters thesis, Universidade Anhanguera de São Paulo, Brasil].

Martins, M. N. P. (2014). Análise das concepções de professores sobre amostragem com o uso do software Tinkerplots 2.0. [Analysis of the conceptions of teachers about sampling through the use of TinkerPlots] [Masters thesis, Universidade Federal de Pernambuco, Brasil].

Mendonça, L. O. (2015). Reflexões e ações de professores sobre modelagem Matemática na Educação Estatística em um grupo colaborativo. [Reflections and actions of teachers regarding mathematical modeling in statistics education] [Doctoral dissertation, Universidade Cruzeiro do Sul, Brasil].

Nacarato, A. M. (2011). A formação do professor de Matemática: Práticas e pesquisas [The formation of the mathematics teacher: Practices and research]. Rematec, 6(9), 27-48.

Nóvoa, A. (1995). Formação de professores e profissão docente. [Teacher training and teaching profession] In A. Nóvoa (Ed.), Os professores e sua formação (pp. 15-34). Dom Quixote.

Nunes, C. M. F. (2001). Saberes docentes e formação de professores: Um breve panorama da pesquisa brasileira. [Teaching knowledge and teacher education: A brief overview of Brazilian research] Educação \& Sociedade, 22(74), 27-42.

Oliveira, E. G. (2014). Raciocínio combinatório na resolução de problemas nos anos iniciais do ensino fundamental: Um estudo com professores. [Combinatory reasoning in problem solving in early childhood education: A study with teachers] [Masters thesis, Pontifícia Universidade Católica de São Paulo, Brasil].

Oliveira, S. A. P. (2016). Educação Estatística em escolas do povo Xukuru do Ororubá. [Statistics education in Xukuru do Ororubá (indigenous peoples) schools] [Masters thesis, Universidade Federal de Pernambuco, Brasil]. 
Rodrigues, M. R. (2018). Estudo sobre as concepções de professores do ensino básico em relação à aleatoriedade e probabilidade. [Study regarding the conceptions in relation to randomness and probability of elementary school teachers] [Doctoral dissertation, Pontifícia Universidade Católica de São Paulo, Brasil].

Serra, E. K. (2016). Conhecimentos de professores para o ensino da leitura e construção de gráficos estatísticos na educação básica. [Knowledge of teachers regarding teaching reading and construction of statistical graphs in elementary school] [Masters thesis, Universidade Anhanguera de São Paulo, Brasil].

Souza, A. C. (2013). O desenvolvimento profissional de Educadoras da Infância: Uma aproximação à Educação Estatística. [Professional development for statistics teaching: A collaborative project to a multidimensional development with middle-school mathematics teachers] [Doctoral dissertation, Universidade Cruzeiro do Sul, Brasil].

Souza, L. O. (2013). O desenvolvimento profissional de professores em Estatística: um projeto multidimensional de formação colaborativa. [Professional development for statistics teaching: A collaborative project to a multidimensional development with middle-school mathematics teachers] [Doctoral dissertation, Universidade Cruzeiro do Sul, Brasil, 2013].

Teixeira, D. F. (2017). Educação financeira no Ensino Fundamental: Conhecimentos identificados em um grupo de professores de 5. ${ }^{\circ}$ ano. [Financial education in elementary school: Identification of knowledge in a group of fifth-grade teachers] [Masters thesis, Pontifícia Universidade Católica de São Paulo, Brasil].

Teixeira, J. (2015). Um estudo diagnóstico sobre a percepção da relação entre educação financeira e matemática financeira. [A diagnostic study regarding the perception of the relationship between financial education and financial mathematics] [Doctoral dissertation, Pontifícia Universidade Católica de São Paulo, Brasil].

Tinti, D. S. (2017). O papel de um grupo colabortivo na superação dos desafios enfrentados por professores principiantes de matemática. [The role of a collaborative group in overcoming the challenges faced by beginning mathematics teachers] Revista de Educação Matemática, 14(16), $34-44$.

Votto, T. R. (2018). As potencialidades lúdicas nas estratégias para o ensino e a aprendizagem estatística nos anos iniciais do ensino fundamental. [Ludic potential of strategies for teaching statistics in early childhood education] [Masters thesis, Universidade Federal do Rio Grande do Sul, Brasil].

DOUGLAS DA SILVA TINTI

Universidade Federal de Ouro Preto - Campus Morro do Cruzeiro Departamento de Educação Matemática (DEEMA) Ouro Preto/Minas Gerais, Brasil. CEP: 35400-000 